\title{
Risk factors for readmission following colorectal cancer surgery
}

\section{Kolorektal kanser cerrahisi sonrası yeniden başvuru için risk faktörleri}

\author{
Mustafa Hasbahçeci ${ }^{1}$, Ŏguz İdiz², Merve Büşra Cengiz ${ }^{1}$, Gökhan Cipe ${ }^{3}$, Naim Memmi ${ }^{1}$, \\ Fatma Ümit Malya ${ }^{1}$, Adem Akcakaya ${ }^{1}$, Mahmut Müslümanoğlu ${ }^{4}$ \\ ${ }^{1}$ Bezmialem Vakıf University Faculty of Medicine Department of General Surgery, İstanbul, Turkey \\ ${ }^{2}$ Şişli Education and Research Hospital Department of General Surgery, İstanbul,Turkey \\ ${ }^{3}$ Medicana Hospital, İstanbul, Turkey \\ ${ }^{4}$ İstanbul University Faculty of Medicine Department of General Surgery, İstanbul, Turkey
}

Dergiye Ulaşma Tarihi: 27.06.2016 Dergiye Kabul Tarihi: 21.10.2016 Doi: 10.5505/aot.2017.38247

\section{ÖZET}

Amaç: Kolorektal kanser cerrahisi sonrası yeniden başvurunun görülme sıklığı ve oluşumu için yüksek riskli hasta gruplarının tanımlanması için gerekli parametreler halen net olarak belirlenmemiştir.

Gereç ve Yöntemler: Bu çalışma, prospektif bir veri tabanı kullanılarak kolorektal kanser cerrahisi geçirmiş olan hastaların retrospektif analizidir. Taburculuktan sonraki ilk 30 gün içerisinde hastane yatışı gerektiren yeniden başvuru asıl değişken olarak belirlendi.

Bulgular: Toplam 187 kolorektal kanser cerrahisi geçiren hasta dikkate alındığında, yaş ortalaması 59,9 $\pm 13,5$

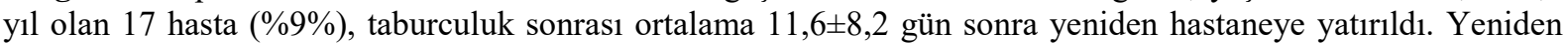
başvurunun en sik rastlanılan etyolojik sebepleri arasında enfektif komplikasyonlar $(n=5)$, eviserasyon $(n=3)$, anastomoz problemleri $(n=3)$ ve intraabdominal kanama/asit gelişimi $(n=3)$ yer almaktaydı. Yeniden başvuru ile erkek cinsiyet ( $p=0.033)$, açık cerrahiye dönüş ( $p=0.009)$, ilk yatış esnasında herhangi bir komplikasyon gelişimi $(p=0.025)$, herhangi bir eş zamanlı çoklu organ rezeksiyon gerekliliği $(p=0.048)$ ve $\mathrm{T}$ evresi $(p=0.046)$ arasında anlamlı ilişki olduğu gösterildi. Lojistik regresyon analizi, bu faktörler arasından erkek cinsiyet $(p=0.041)$ ve herhangi bir eş zamanlı çoklu organ rezeksiyon gerekliliğinin ( $\mathrm{p}=0.045)$ yeniden başvuru gelişimi ile anlamlı bir şekilde ilişkili olduğunu gösterdi.

Sonuç: Her ne kadar erkek cinsiyet ve herhangi bir eş zamanlı çoklu organ rezeksiyon gerekliliğinin yeniden başvuru gelişimi ile anlamlı bir şekilde ilişkili olduğu gösterilmekle birlikte, kişisel risk faktörlerinin belirlenmesi için ileri çalışmalara ihtiyaç vardır.

Anahtar kelimeler: yeniden başvuru, kolorektal kanser, kolorektal cerrahi, komplikasyon

\begin{abstract}
Objective: Incidence of re-admission after colorectal cancer surgery and the parameters to define high-risk patients for its occurrence remain to be clarified.

Material and Methods: This study was a retrospective analysis of patients with colorectal cancer surgery using a prospective database. Readmission necessitating hospitalization within the first 30 days following discharge was regarded as major outcome.

Results: Considering a total of 187 colorectal cancer patients, $17(9 \%)$ with a mean age of $59.9 \pm 13.5$ years were re-hospitalized after a mean of $11.6 \pm 8.2$ days following discharge. Infective complications $(n=5)$, evisceration $(n=3)$, anastomotic problems $(n=3)$ and intraabdominal hematoma/ascites $(n=3)$ were the most commonly encountered surgical etiologies for readmission. There was a close relationship between readmission and male sex $(p=0.033)$, conversion to open surgery $(p=0.009)$, development of any type of complication during index admission ( $\mathrm{p}=0.025)$, need for concurrent multi-organ resections of any type $(\mathrm{p}=0.048)$ and $\mathrm{T}$ stage $(\mathrm{p}=0.046)$. Logistic regression analysis showed that male sex $(\mathrm{p}=0.041)$ and need for concurrent multi-organ resections of any type $(\mathrm{p}=0.045)$ were significantly related with development of readmission.

Conclusion: Although male sex and need for concurrent multi-organ resections were shown to be related with development of readmission, more research is needed to individualize risk factors.
\end{abstract}

Keywords: readmission, colorectal cancer, colorectal surgery, complication

\section{Introduction}

Colorectal cancer is the third most common cancer in developed countries, and the number of new cases is expected to rise in each year (1-3). Surgery still remains the cornerstone of its treatment. Operated patients are facing the risk factors that cause readmissions after the 
surgery such as venous thromboembolism, ileus, infection, anastomotic leakage and hemorrhage (4).

As an indicator of medical care, readmission rate after colorectal cancer surgery reflecting late complications and breach of initial care can be seen in up to $24 \%$ of the patients (5-7). Data with regard to readmission of the patients after colorectal surgery may give important information following oncologic and surgical outcomes (8).

Possible effect of surgical and oncological parameters on development of readmission following colorectal surgery has not been described well (6,9-11). Knowledge of the incidence and cause of readmissions is thought to cause improvement in morbidity of colorectal cancer and its surgery and mitigation of sequelae of these complications (9).

The aim of this study was to investigate the parameters affecting readmission to the hospital after the surgery for colorectal cancer and to define high-risk patients who may benefit from a more intensive post-discharge monitoring.

\section{Material and Methods}

\section{Study population}

This study included all patients who were undergone resection due to colorectal cancer between November 2010 and February 2013. It was a retrospective analysis of prospectively collected data of the patients with major excisional colonic or rectal procedures for colorectal cancer. Institutional review board approval was taken. This study has been conducted in accordance with the declaration of Helsinki. Informed consent could not be taken from the patients due to the retrospective design of the study. The patients who had developed any type of major complication during the index admission were not excluded from the study.

\section{Variables}

Variables including patients' demographics (age, sex), admission status (elective or emergent), intraoperative details (mode and type of surgery, ostomy status, concurrent multi-organ resections), postoperative complications and length of hospital stay (LOHS) during the index admission and pathological features of the tumor ( $\mathrm{T}$ and $\mathrm{N}$ stages) were recorded.

Hand assisted-laparoscopic or robotic surgery was not performed. Extracorporeal anastomosis was used after the removal of the specimen through an incision rather than the incision used for ostomy. Operations were grouped into the following categories: right hemicolectomy, left hemicolectomy, total colectomy, anterior or low anterior resection with stoma and abdominoperineal resection. The number of days from the day of the operation until the discharge from the hospital was calculated as LOHS.

Readmission which was defined as the hospitalization within the first 30 days following discharge was regarded as the major outcome of this study. Data with regard to readmissions was collected from this database, and a resident in surgery conducted a 30-day follow-up via phone call.

\section{Statistical analysis}

All statistics were performed using SPSS 15.0 for Windows (SPSS, Inc., Chicago, IL, USA). All variables of the study were analyzed in relation to the risk of readmission. Continuous variables were expressed as mean \pm standard deviation (SD). Categorical variables were expressed as frequencies. Comparisons between patients with and without readmission were evaluated by Pearson chi-square test or Fisher's exact test or Mann-Whitney test. Backward Stepwise logistic regression model (Odds ratio (OR) with confidence interval of $95 \%$, chi square value of 13,032 with 90.9 percentage correct) was constructed to evaluate the effect of age, sex, mode of admission, type and mode of surgery, ostomy status, multiorgan resections, postoperative complications, length of hospital stay and pathological features of the tumor on the major outcome (readmission). The differences were considered statistically significant if the $p$ value was equal to or less than 0.05 .

\section{Results}

A total of 187 colorectal cancer patients who had undergone major excisional colorectal surgery were identified using the database. Mean age of the patients was $59.9 \pm 13.5$ years 
with male to female ratio of 1.83 [121 male

$(64.7 \%)$ and 66 female patients (35.3\%)].

Table 1: Demographic and clinical characteristics of the patients $(\mathrm{N}=187)$

\begin{tabular}{|c|c|c|}
\hline Parameter & & Overall (n (\%)) \\
\hline \multirow[t]{2}{*}{ Sex } & Male & $121(64.7)$ \\
\hline & Female & $66(35.3)$ \\
\hline \multirow[t]{2}{*}{ Mode of admission } & Emergent & $25(13.4)$ \\
\hline & Elective & $162(86.6)$ \\
\hline \multirow[t]{3}{*}{ Mode of surgery } & Open & $89(47.6)$ \\
\hline & Laparoscopic & $85(45.4)$ \\
\hline & Conversion & $13(7)$ \\
\hline \multirow[t]{5}{*}{ Type of operation } & Left hemicolectomy & $73(39)$ \\
\hline & Right hemicolectomy & $48(25.7)$ \\
\hline & $\begin{array}{l}\text { Anterior-low anterior resection with } \\
\text { diverting ileostomy }\end{array}$ & $50(26.7)$ \\
\hline & Subtotal-total colectomy & $7(3.8)$ \\
\hline & Abdominoperineal resection & $9(4.8)$ \\
\hline \multirow[t]{3}{*}{ Ostomy status } & None & $99(53)$ \\
\hline & Diverting ileostomy & $52(27.8)$ \\
\hline & End ileo/colostomy & $36(19.2)$ \\
\hline Multi-organ resections & & $24(12.8)$ \\
\hline $\begin{array}{l}\text { Number of complications during } \\
\text { index admission }\end{array}$ & & $34(18.2)$ \\
\hline Readmission & & $17(9)$ \\
\hline T stage $^{\mu}$ & & $3 \pm 0.7$ \\
\hline $\mathrm{N}$ stage $^{\mu}$ & & $0.7 \pm 0.8$ \\
\hline LOHS during index admission ${ }^{\mu}$ & & $8.7 \pm 5.9$ \\
\hline
\end{tabular}

Demographic and clinical characteristics of the patients were summarized in Table 1. During the index admission, a total of 34 complications $(18.2 \%)$ were seen in 28 patients (Table 2).

Infective complications $(n=6)$ and anastomotic problems $(n=6)$ were the leading etiologies. Besides colorectal cancer surgery alone, multi-organ resections were required in 24 patients (12.8\%). Resection of the gynecological organs $(n=6)$ and additional the small bowel or colonic resections $(n=5)$ were the leading procedures. Others were metastasectomy $(n=4)$, splenectomy $(n=3)$, resection of the organs of the urinary system with primary repair $(n=3)$, wedge resection of the stomach $(\mathrm{n}=2)$ and cholecystectomy $(\mathrm{n}=1)$.

Considering all patients, 17 patients (9\%) were re-hospitalized after a mean of $11.6 \pm 8.2$ days following discharge. Infective complications including intraabdominal abscess, wound and urinary tract infections $(\mathrm{n}=5), \quad$ evisceration $\quad(\mathrm{n}=3), \quad$ anastomotic problems $(\mathrm{n}=3)$ and intraabdominal hematoma/ascites $(n=3)$ were the most commonly observed surgical complications to cause readmission (Table 3). The mean length of hospital stay after re-hospitalization was $6.65 \pm 5.0$ days. For these patients, surgical and percutaneous interventions were required in eight and four of them, respectively.

There were no effect of age, mode of admission, ostomy status, type of the operation, maximum diameter and $\mathrm{N}$ stage of the tumor on readmission (Table 4). However, male sex $(\mathrm{p}=0.033)$, conversion to open surgery $(\mathrm{p}=0.009)$, development of any type of complication during index admission $(\mathrm{p}=0.025)$, need for concurrent multi-organ resections of any type $(\mathrm{p}=0.048)$ and $\mathrm{T}$ stage of 
tumor $(\mathrm{p}=0.046)$ were positively correlated with future readmissions. Laparoscopic surgery was also shown to be a protective factor to prevent readmission $(\mathrm{p}=0.009)$.

Table 2: Complications during index admission ${ }^{\beta}$

\begin{tabular}{|l|l|l|l|}
\hline Etiology & & N & n \\
\hline Surgical site infections & Organ/space & 6 & \\
\hline & Superficial-deep incisional & & 4 \\
\hline Anastomotic leakage & & 6 & \\
\hline Intraabdominal hematoma/ascites & & 4 & \\
\hline Intestinal obstruction & & 4 & \\
\hline Evisceration & & 3 & \\
\hline Urinary fistula & & 3 & \\
\hline Non-surgical complications & & 8 & \\
\hline & Arrhythmias & & 6 \\
\hline & Pulmonary embolism & & 1 \\
\hline & Stroke & & 1 \\
\hline
\end{tabular}

$\beta$ : a total of 34 complications in 28 patients

Table 3: Etiologic factors for readmission

\begin{tabular}{|l|l|l|l|}
\hline Etiology & & N & n \\
\hline Infective complications & & 5 & \\
\hline & $\begin{array}{l}\text { Organ/space surgical site } \\
\text { Superficial-deep incisional } \\
\text { surgical site }\end{array}$ & 2 \\
\hline & Urinary tract & 2 \\
\hline Evisceration & & 3 & 1 \\
\hline Anastomotic leakage & & 3 & \\
\hline $\begin{array}{l}\text { Intraabdominal } \\
\text { hematoma/ascites }\end{array}$ & 3 & \\
\hline Urinary fistula & & 1 & \\
\hline Intestinal obstruction & & 1 & \\
\hline Pulmonary embolism & & 1 & \\
\hline
\end{tabular}

Logistic regression analysis showed that male sex $(p=0.041, O R=2,254$ with a range of 1.033 to 4.918) and need for concurrent multi-organ resections of any type $(\mathrm{p}=0.045, \mathrm{OR}=1.886$ with a range of 1.015 to 3.503 ) were significantly related with development of readmission.

\section{Discussion}

Hospital readmission as an emerging quality indicator has been defined for patients with acute myocardial infarction, congestive heart failure and pneumonia (4). It is generally accepted that surgical patients are at high risk for readmission due to the increased risks of infection, anastomotic leak, ileus, re-bleeding, and thromboembolic events (12). Therefore, recent studies have focused on 30-day readmission rates after several surgical operations including colorectal surgery as a marker of quality of surgical care $(12,13)$.

It was also believed that delayed surgical and medical complications appearing 
within a month after discharge were the most important cause for the unplanned readmissions. In addition, the real incidence of re-admission seems to be difficult to assess because of differences in methodology, time frames for readmission, patient groups, and in whether planned readmissions were included $(11,13)$. Therefore, unplanned re-admissions within the postoperative 30 days were studied in the present study to evaluate readmissions caused by surgical and medical complications.

Although the reported rates of readmission after colorectal surgery varied from $7 \%$ to $25 \%$, it usually occurs in almost $10 \%$ of the cases $(4,7,14-16)$. In the present study, the rate was detected as $9 \%$. Besides being a quality indicator, it was also shown that hospital readmission was an independent risk factor for death within one year of the operation (17). In Schneider's study (8), mortality during the unplanned readmission was twice higher than that of the index admission. It was also noted that median and 3 -year survival rates were also worse in patients with early readmission. However, lack of the data with regard to survival of the patients prevents us to evaluate the possible impact of readmission on survival. Future prospective studies are needed to clarify the relation between readmission and survival after colorectal cancer surgery.

The association between enhanced recovery after surgery protocols and rate of readmission remains to be clarified. In our center, any type of enhanced recovery or fasttrack protocols have not been applied to our patients. Although it was thought that most of the unplanned readmissions were linked to an early discharge and shorter hospital stay, this finding was not observed by other researchers $(12,13,18-20)$. There are some authors who advocate that decreasing the duration of hospital stay of the patients after colorectal surgery would help to reduce the expenses related to health, to prevent nosocomial infections and to increase the quality of patient's life by sending him/her to home quickly (10). Although any type of enhanced recovery after surgery protocol has not been applied to our patients, nosocomial infections were not encountered in the present study causing delayed discharge. A surveillance study of 149,622 patients showed that admission rates following discharge after a 30day hospital stay increased from $10.2 \%$ to $13.7 \%$ although the duration of hospital stay decreased from 14 days to 10.6 days between 1986 and 2005 (8). In a meta-analysis, it has been shown that implementation of the enhanced recovery after surgery pathways in colorectal surgery caused $12 \%$ reduction in total complication rates without compromising patient safety (18). It was also interesting to find increased readmissions in cases with longer hospital stay caused either by surgical complications during the index admission or initially older and sicker patients $(8,10,13)$. In an English NHS trust study with a period of ten years, the relationship between length of hospital stay and subsequent readmission after major elective colorectal surgery was shown to be statistically insignificant (14). However, readmission rates have increased from $6.74 \%$ to $8.64 \%$ in colonic surgery and $8.10 \%$ to $11.86 \%$ in rectal surgery besides two day decrease in median hospital stay. In the present study, it could not be possible to detect such significant association with the length of hospital stay (mean length of hospital stay of 8.12 and 8.72 days in patients with and without readmission, respectively). Therefore, future studies are still needed to clarify effect of the length of hospital stay on the development of readmission after major colorectal surgery.

Defining the high-risk patient based on the factors directly related with readmission may be the most important preventive measure, although there were numerous studies which attempted to identify predictors or early readmission with mixed results (13). In previous studies, it was shown that it was possible to estimate the future re-admissions with the presence of some risk factors including longer operating time, older patient, higher body mass index, development of any complication during the index admission, identity of the surgeon and increased need of blood transfusions $(6,8,15,21,22)$. Our results showed that male gender, conversion to open surgery, necessity of multi-organ resections, development of complication during index admission and $\mathrm{T}$ stage were significantly related with readmission. In the present study, the etiologic factors for readmission and complications during the index admission showed great similarity. Development of any 
type of major complication during the index admission was not regarded as an exclusion criterion. Instead, it was evaluated as a risk factor for readmission. In comparison to open and converted cases, laparoscopic surgery was shown to be inversely related with readmission in accordance with Alves' study (22). In Manilich's study (15), it was shown that length of surgery, body mass index, and the surgeon were the top three risk factors for readmission. Wick et al (4) reported similar 30-day readmission rates in patients who were younger and older than 65 years, suggesting that readmission may be a result of the operative procedures and perioperative complications rather than of the underlying patient comorbidities. They also showed that length of stay, discharge to a stoma, and inhospital complications like surgical site infections were the factors associated with readmission. In Kirans's study (10), index stays greater than 6 days and steroid use were found to be related with readmission. O'Brien et al (11) showed that inflammatory bowel disease and pulmonary comorbidities were the independent risk factors. Distal bowel resection with stoma, benign diagnosis, young age, social deprivation and high provider volume status were also shown to be the independent predictors for 28-day readmission (14). By considering all these factors, it seems to be very difficult to state precisely the highrisk patient for readmission as highlighted in a systematic review by Damle $(4,16)$.

In previous studies related with readmission after colorectal surgery, inflammatory bowel disease has constituted a significant proportion of all cases, in contrary to our hospital in which the number of such patients requiring surgery was very low compared to colorectal cancer $(21,22)$. Therefore, such cases were excluded from this study.

Although some readmissions are caused by inevitable factors, preventable causes comprise great majority of readmissions. In each case of readmission, it may be possible to decide whether it is preventable or not. It was also surprisingly noted that majority of the readmissions were occurred within the first two weeks after the discharge in accordance with that of 11.6 days in this study. Among the most common readmission diagnoses, operative complications, dehydration and postoperative infection were reported (8). However, evisceration, infective complications and intraabdominal abscess were found to be the most common reasons for readmission in the present study. Considering these pathologies as the most common reasons for readmission, it may be expected that there should be some clinical and/or laboratory evidences at the time of discharge. Although Azimuddin et al (6) did not observe a significant difference according to the values of white blood cell count and temperature at discharge among the patients with or without readmission; it may be a logical measure to perform a meticulous evaluation of the patient during the last 48 hours before discharge.

Retrospective design of the present study and lack of the data related with survival are the major limitations to reach more significant conclusions.

In conclusion, readmission after colorectal cancer surgery should be regarded as an important event seen in almost $10 \%$ of the patients. Although it does not seem to be related with mortality, additional LHOS with some percutaneous and surgical interventions are required. Male sex, conversion to open surgery, development of any type of complication during index admission, need for concurrent multi-organ resections of any type and $\mathrm{T}$ stage of tumor were thought to be positively correlated with future readmissions, contrary to laparoscopic surgery as a possible predictive factor. However, male sex and need for concurrent multi-organ resections of any type were shown to be significantly related with development of readmission. Therefore, more research is needed to identify and to individualize the parameters significantly associated with a higher risk of readmissions after colorectal cancer surgery. Additionally, each institution should try to determine the possible risk factors for application of preventive measures including longer LOHS or additional imaging techniques.

Conflict of Interest: None 


\section{References}

1. Jemal A, Siegel R, Xu J, Ward E. Cancer statistics, 2010. CA Cancer J Clin 2010;60:277-300

2. Chokshi RJ, Abdel-Misih S, Bloomston M. Surgical management of colorectal cancer: A review of the literature. Indian J Surg 2009;71:350-5

3. Bayar B, Yılmaz KB, Akıncı M, Şahin A, Kulaçoğlu $\mathrm{H}$. An evaluation of treatment results of emergency

4. versus elective surgery in colorectal cancer patients. Ulus Cerrahi Derg 2015;32:11-7

5. Wick EC, Shore AD, Hirose K, et al. Readmission rates and cost following colorectal surgery. Dis Colon Rectum 2011;54:1475-9

6. Delaney CP, Fazio VW, Senagore AJ, Robinson B, Halverson AL, Remzi FH. 'Fast track' postoperative management protocol for patients with high comorbidity undergoing complex abdominal and pelvic colorectal surgery. Br J Surg 2001;88:1533-8

7. Azimuddin K, Rosen L, Reed JF 3rd, Stasik JJ, Riether RD, Khubchandani IT. Readmissions after colorectal surgery cannot be predicted. Dis Colon Rectum 2001;44:942-6

8. Ashton CM, Wray NP. A conceptual framework for the study of early readmission as an indicator of quality of care. Soc Sci Med 1996;43:1533-41

9. Schneider EB, Hyder O, Brooke BS, et al. Patient readmission and mortality after colorectal surgery for colon cancer: impact of length of stay relative to other clinical factors. J Am Coll Surg 2012;214:3908

10. Kwaan MR, Vogler SA, Sun MY, et al. Readmission after colorectal surgery is related to preoperative clinical conditions and major complications. Dis Colon Rectum 2013;56: 1087-92

11. Kiran RP, Delaney CP, Senagore AJ, Steel M, Garafalo T, Fazio VW. Outcomes and prediction of hospital readmission after intestinal surgery. J Am Coll Surg 2004;198:877-83

12. O'Brien DP, Senagore A, Merlino J, Brady K, Delaney C. Predictors and outcome of readmission after laparoscopic intestinal surgery. World J Surg 2007;31:2430-5

13. Guinier D, Mantion GA, Alves A, Kwiatkowski F, Slim K, Panis Y. Risk factors of unplanned readmission after colorectal surgery: a prospective, multicenter study. Dis Colon Rectum 2007;50:131623
14. Kelly M, Sharp L, Dwane F, Kelleher T, Comber H. Factors predicting hospital length-of-stay and readmission after colorectal resection: a populationbased study of elective and emergency admissions. BMC Health Serv Res 2012;12:77

15. Faiz O, Haji A, Burns E, Bottle A, Kennedy R, Aylin P. Hospital stay amongst patients undergoing major elective colorectal surgery: predicting prolonged stay and readmissions in NHS hospitals. Colorectal Dis 2011;13:816-22

16. Manilich E, Vogel JD, Kiran RP, Church JM, Seyidova-Khoshknabi D, Remzi FH. Key factors associated with postoperative complications in patients undergoing colorectal surgery. Dis Colon Rectum 2013;56:64-71

17. Damle RN, Alavi K. Risk factors for 30-d readmission after colorectal surgery: a systematic review. J Surg Res 2016;200:200-7

18. Greenblatt DY, Weber SM, O'Connor ES, LoConte NK, Liou JI, Smith MA. Readmission after colectomy for cancer predicts one-year mortality. Ann Surg 2010;251:659-69

19. Lv L, Shao YF, Zhou YB. The enhanced recovery after surgery (ERAS) pathway for patients undergoing colorectal surgery: an update of metaanalysis of randomized controlled trials. Int $\mathrm{J}$ Colorectal Dis 2012;27:1549-54

20. Rona K, Choi J, Sigle G, Kidd S, Ault G, Senagore AJ. Enhanced recovery protocol: implementation at a county institution with limited resources. Am Surg 2012;78:1041-4

21. Hoffman RL, Bartlett EK, Ko C, Mahmoud N, Karakousis GC, Kelz RR. Early discharge and readmission after colorectal resection. J Surg Res 2014;190:579-86

22. Alves A, Panis Y, Mathieu P, Mantion G, Kwiatkowski F, Slim K. Postoperative mortality and morbidity in French patients undergoing colorectal surgery: results of a prospective multicenter study. Arch Surg 2005;140:278-83

23. Alves A, Panis Y, Slim K, Heyd B, Kwiatkowski F, Mantion G. French multicentre prospective observational study of laparoscopic versus open colectomy for sigmoid diverticular disease. $\mathrm{Br} \mathrm{J}$ Surg2005;92:1520-5 